\title{
Deskripsi Waktu Tunggu dan Kepuasan Pasien di Klinik
}

\author{
Yesaya Ukago, Dian Mawarni* \\ Universitas Negeri Malang, Jl. Semarang No. 5 Malang, Jawa Timur, Indonesia \\ *Penulis korespondensi, Surel: dian.mawarni.fik@um.ac.id
}

Paper received: 1-10-2021; revised: 19-10-2021; accepted: 25-10-2021

\begin{abstract}
This study aims to see whether or not there is a relationship between waiting time and patient satisfaction at DAQU Sehat Malang. This research is a correlational study, where the data obtained is secondary data from the records collected at the DAQU Sehat Malang clinic. The results obtained on the Waiting Times variable with patient satisfaction indicate that the correlation between the two variables is significant because the significant value obtained $(0.005)$ is smaller than the significant value used ( $p$ less than 0.01). The correlation value of the spearman test results ( $r$ ) of $(0.455)$ indicates that the direction of the correlation is positive. This means that the waiting time according to the standard will make respondents more satisfied.
\end{abstract}

Keywords: waiting time; patient satisfaction

\begin{abstract}
Abstrak
penelitian ini bertujuan untuk melihat ada atau tidak adanya hubungan Waktu Tunggu Dan Kepuasan Pasien di DAQU Sehat Malang. Penelitian ini merupakan penelitian korelasional, dimana data yang didapat merupakan data sekunder hasil pencatatan yang terkumpul pada klinik DAQU Sehat Malang. Hasil penelitian yang didapatkan pada variabel Waiting Times/waktu tunggu dengan kepuasan pasien memperlihatkan bahwa hubungan antara kedua variabel tersebut adalah bermakna karena nilai signifikan yang diperoleh $(0,005)$ lebih kecil dari nilai signifikan yang digunakan ( $\mathrm{p}$ kurang dari $0,01)$. Nilai korelasi dari hasil uji spearman (r) sebesar $(0,455)$ menunjukkan bahwa arah korelasi positif. Artinya waktu tunggu yang sesuai standar akan membuat responden semakin puas.
\end{abstract}

Kata kunci: waktu tunggu; kepuasan pasien

\section{Pendahuluan}

Dalam undang-undang kesehatan nomor 44 tahun 2009 tentang pelayanan kesehatan pasal 1 dinyatakan bahwa rumah sakit sebagai institusi pelayanan kesehatan yang memberikan pelayanan kesehatan perorangan yang menyediakan pelayanan rawat inap, rawat jalan, gawat darurat.

Unit instalasi rawat jalan menangani penerimaan pasien yang berobat jalan maupun yang akan di rawat di rumah sakit. Pelayanan instalasi rawat jalan pertama kali dilakukan di loket karcis sampai selesai pemberian resep di apotik. Banyak masyarakat yang tidak puas dengan pelayanan yang diberikan oleh rumah sakit, seperti pemeriksaaan yang kurang diperhatikan oleh petugas kesehatan, keterampilan petugas, saran /fasilitas yang kurang memadai, serta lamanya waktu tunggu untuk mendapatkan pelayanan, rendahnya kinerja pelayananan yang akan membangun citra buruk pada pelayanan rumah sakit. Pasien yang tidak puas akan menceritakan kepada temannya, begitu sebaliknya semakin tinggi kinerja pelayanan yang diberikan akan menjadi nilai tambah bagi rumah sakit, dalam hal ini pasien akan puas terhadap pelayanan yang akan diberikan (Pohon,2011).

Waktu tunggu diartikan sebagai waktu yang digunakan oleh pasien untuk mendapatkan layanan rawat jalan dan rawat inap dari loket pendaftaran sampai ke ruang pemeriksaan 
dokter. Menunggu dalam waktu yang lama menjadikan ketidakpuasan pasien (depkes RI, 2010). Mengurangi waktu tunggu bisa meningkatkan kepuasan pasien di rawat jalan (Camacho et al,2007). Tiga penyebab utama lamanya waktu pelayanan pasien berupa: lamanya waktu pendaftaran di loket, terbatasnya dokter, banyaknya pasien, terbatas staf pelayanan kesehatan lainnya (zairul, 2011). Waktu tunggu di rawat jalan yang kurang dari 60 menit, maka kepuasan pasien diatas 90\%, (PERMENKES RI.NO. 129 tahun 2008).

Waktu tunggu yang cukup lama merupakan faktor ketidakpuasan pasien. Mengukur hubungan waktu tunggu dan kepuasan pasien di pelayanan kesehatan dengan menggunakan skala 0 - 10 poin. Waktu tunggu secara signifikan memprediksi peringkat penyediaan layanan kesehatan, ketika waktu pemeriksaan oleh dokter 5 menit peringatan waktu tunggu, ketika waktu pemeriksaan oleh dokter lebih dari 5 menit peringkat penyediaan layanan kesehatan menurut sebesar 0,1 poin rating untuk setiap 10 menit peningkatan waktu tunggu. Waktu tunggu berkaitan erat dengan kepuasan pasien, waktu tunggu pelayanan yang lama mengakibatkan keinginan untuk berobat kembali ke penyedia layanan kesehatan mengalami penurunan (Chamocoe et al,2011).

Kepuasan didefinisikan kepuasan pasien dengan ruang tunggu yang nyaman dalam menunggu pelayanan kesehatan, kepuasan pasien saat mendapatkan pelayanan yang diberikan oleh petugas kesehatan di ruang pelayanan dengan mendapatkan pelayanan yang diberikan oleh petugas kesehatan di ruang pelayanan, dengan mendapatkan pelayanan yang diharapkan kemungkinan merujuk teman atau kerabat berobat pelayanan kesehatan tersebut (Michael et, al 2013). Pelayanan pasien di rawat jalan di mulai pada saat pendaftaran di loket kartu rekam medis, birokrasi yang berbelit belit dan lama pada saat pendaftaran membuat pasien tidak sabar dan sering mengeluh lamanya pelayanan sehingga pasien tidak merasa puas (soebarto,2011).

Kualitas pelayanan terhadap masyarakat dipengaruhi oleh sarana dan fasilitas di rawat jalan. Kepuasan pasien pengguna jasa layanan kesehatan dipengaruhi oleh sarana yang memadai dan akses yang mudah dan fasilitas rumah sakit yang lengkap.

Jumlah kunjungan pasien di instalasi gawat jalan DAQU Sehat malang pada tahun 2017 terutama di klinik DAQU berdasarkan data dari medical record 6086 pasien, jumlah kunjungan dalam bulan Maret 1.43, dan April 2018 sebanyak 1807 pasien. Klinik DAQU adalah poliklinik yang dalam proses pemberian pelayanan kesehatan paling lama.

Berdasarkan dengan masalah diatas peneliti mengambil, judul Deskripsi Waktu Tunggu Dan Kepuasan Pasien di DAQU Sehat Malang. Penelitian ini bermanfaat bagi 1) peneliti, memberikan kesempatan peneliti untuk menerapkan khasanah keilmuan kesehatan masyarakat selama masa perkuliahan dengan secara aktif berinteraksi dengan masyarakat dalam upaya promosi kesehatan, 2) bagi Dinas Kesehatan kabupaten kota, secara empiris dapat menjadi masukan dan dasar evaluasi bagi program yang telah dijalankan pemerintah serta memberikan strategi dan rekomendasi bagi instansi berkepentingan terutama Dinas Kesehatan kabupaten kota dalam upaya mencapai tujuan dari Renstra Kemenkes dan RPJMN serta peningkatan status kesehatan masyarakat di wilayah kerjanya, 3) bagi Jurusan Kesehatan Masyarakat, Sebagai bahan skripsi atau syarat kelulusan dalam menempuh jenjang strata satu (S-1) jurusan Kesehatan Masyarakat, sehingga nantinya juga dapat berguna sebagai rujukan penelitian bagi civitas akademika di lingkungan jurusan Kesehatan Masyarakat. 


\section{Metode}

Penelitian ini memakai metode deskriptif dengan pendekatan studi Cross-sectional, yaitu peneliti hanya melakukan pengamatan dan pengukuran variabel pada sekali waktu tertentu saja. Tujuan penelitian ini untuk membuat deskripsi secara sistematis, faktual dan akurat mengenai fakta, sifat, serta hubungan antar fenomena yang diselidiki. Maka penelitian ini, dimaksudkan untuk melihat mendeskripsikan, waktu tunggu dan kepuasan pasien di klinik DAQU pada instalasi rawat sakit DAQU Sehat malang.

Alur penelitian di mulai dari menentukan populasi terjangkau kemudian menentukan sampel dengan metode purposive sampling, yaitu pasien yang berkunjung ke politik mata dengan status kunjungan lama/ berulang yang datang pada 15 Juni -15 Juli 2020. Waiting times/ waktu tunggu dimulai saat pasien mendaftar di loket kartu kemudian status tiba di klinik DAQU dicatat lagi waktunya sampai selesai pasien mendapat pelayanan dari dokter/perawat. Pemberian kuesioner kepada pasien dilakukan pada saat selesai pelayanan di klinik DAQU, setelah mendapat data yang diinginkan kemudian mentabulasi data dan menganalisa data dengan uji Spearman.

\section{Hasil dan Pembahasan}

\subsection{Analisis Univariat}

\subsubsection{Penyajian Karakteristik Responden}

Dari penelitian yang telah dilaksanakan di DAQU Sehat Malang, diperoleh data dari 37 responden jumlah tertinggi adalah responden dengan kelompok usia 31-40 tahun yaitu 18 $(48,6 \%)$ responden, dan usia responden terkecil berada pada kelompok $<18$ tahun dan $>50$ tahun yaitu masing-masing $3(8,1 \%)$ responden. Jenjang pendidikan tertinggi berada pada responden dengan tingkat pendidikan SMA dan S1 yaitu masing-masing 13 (35,1\%) responden, dan terkecil tingkat pendidikan PAUD, SD dan D3 yaitu $1(2,7 \%)$ responden. Dari segi jenis kelamin responden jumlah terbanyak pada kelompok perempuan yaitu $24(64,9 \%)$, dan paling sedikit berada pada kelompok laki-laki yaitu $13(35,1 \%)$ responden. Beberapa hal tersebut dapat dilihat pada tabel berikut :

Tabel 1. Distribusi Frekuensi Uraian Karakteristik Responden di DAQU Sehat Malang

\begin{tabular}{lcc}
\hline Variabel & Frekuensi & Persentase (\%) \\
\hline Usia Responden & & \\
\hline$<18$ & 3 & 8,1 \\
$18-30$ & 18 & 48,6 \\
$31-40$ & 8 & 21,6 \\
$41-50$ & 5 & 13,5 \\
$>50$ & 3 & 8,1 \\
\hline Jenis Kelamin & & \\
\hline Laki-laki & 13 & 35,1 \\
Perempuan & 24 & 64,9 \\
\hline Pendidikan & & \\
\hline PAUD & 1 & 2.7 \\
SD & 1 & 2.7 \\
SLTA & 13 & 35.1 \\
D3 & 1 & 2.7 \\
S1 & 13 & 35.1
\end{tabular}




\begin{tabular}{lcc}
\hline Variabel & Frekuensi & Persentase (\%) \\
\hline S2 & 6 & 16.2 \\
S3 & 2 & 5.4 \\
\hline
\end{tabular}

Data yang menyangkut karakteristik responden akan dikelompokkan sebagai berikut:

Tabel 2. Distribusi Frekuensi Karakteristik Responden di DAQU Sehat Malang

\begin{tabular}{lcc}
\hline Variabel & Frekuensi & Persentase (\%) \\
\hline Usia Responden & & \\
\hline Anak-anak & 3 & 8.1 \\
Dewasa Muda & 26 & 70.3 \\
Dewasa Madya & 8 & 21.6 \\
\hline Jenis Kelamin & & \\
\hline Laki-laki & 13 & 35,1 \\
Perempuan & 24 & 64,9 \\
\hline Pendidikan & & \\
\hline Pendidikan Rendah & 15 & 40.5 \\
Pendidikan Tinggi & 22 & 59.5 \\
\hline
\end{tabular}

\subsubsection{Waktu Tunggu}

Berikut distribusi waiting times/waktu tunggu menurut responden di DAQU Sehat Malang terlihat pada tabel berikut ini. Ditunjukkan bahwa sebagian besar pasien menyatakan waiting times dengan klasifikasi baik/sesuai standar yaitu 35 (94,6\%) responden, dan sebagian menyatakan waiting times dengan klasifikasi kurang baik/tidak sesuai standar yaitu $2(5,4 \%)$ responden.

Tabel 3. Distribusi Frekuensi Waktu Tunggu di DAQU Sehat Malang

\begin{tabular}{lcc}
\hline \multicolumn{1}{c}{ Waktu Tunggu } & Frekuensi & $\mathbf{0}$ \\
\hline Sesuai Standar & 35 & 94,6 \\
Tidak Sesuai Standar & 2 & 5,4 \\
Total & 37 & 100 \\
\hline
\end{tabular}

\subsubsection{Kepuasan Pasien}

Berikut distribusi motivasi kepuasan pasien menurut responden di DAQU Sehat Malang terlihat pada tabel berikut ini. Ditunjukkan bahwa sebagian besar pasien menyatakan bahwa kepuasan pasien dengan kategori puas yaitu 29 (78,4\%) responden, sedangkan kategori kurang puas $8(21,6 \%)$ responden.

Tabel 4. Distribusi Frekuensi Kepuasan Pasien di DAQU Sehat Malang

\begin{tabular}{|c|c|c|}
\hline Kepuasan Pasien & Frekuensi & $\%$ \\
\hline Kurang Puas & 8 & 21,6 \\
\hline Puas & 29 & 78,4 \\
\hline Total & 37 & 100 \\
\hline
\end{tabular}




\subsubsection{Distribusi Kepuasan Pasien Menurut Usia}

Berikut distribusi motivasi kepuasan pasien menurut usia responden di DAQU Sehat Malang terlihat pada tabel berikut ini. Ditunjukkan bahwa sebagian besar pasien menyatakan bahwa kepuasan pasien berdasarkan usia dengan kategori puas usia dewasa muda yaitu 20 $(54,1 \%)$ responden, sedangkan kategori puas usia dewasa madya yaitu $6(16,2 \%)$ responden dan kategori puas usia anak-anak yaitu $3(8,1 \%)$ responden.

Tabel 5. Distribusi Frekueensi Kepuasaan Pasien Menurut Usia di DAQU Sehat Malang

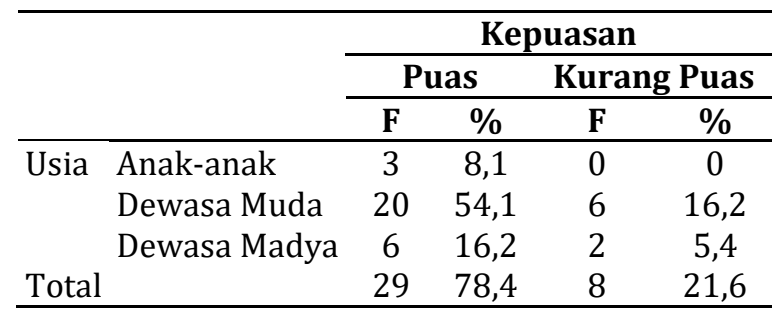

\subsubsection{Distribusi Kepuasan Pasien Berdasarkan Tingkat Pendidikan}

Berikut distribusi kepuasan pasien berdasarkaan tingkat pendidikan responden di DAQU Sehat Malang terlihat pada tabel berikut ini. Ditunjukkan bahwa sebagian besar pasien menyatakan bahwa kepuasan pasien berdasarkan tingkat pendidikan dengan kategori puas berpendidikan tinggi yaitu $18(48,6 \%)$ responden, sedangkan kategori puas berpendidikan rendah yaitu $11(29,7 \%)$ responden.

Tabel 6. Distribusi frekuensi Kepuasan Pasien Menurut Tingkat Pendidikan di DAQU Sehat Malang

\begin{tabular}{llcccc}
\hline & \multicolumn{4}{c}{ Kepuasan } \\
\cline { 3 - 6 } & & \multicolumn{3}{c}{ Puas } & \multicolumn{3}{c}{ Kurang Puas } \\
\cline { 3 - 6 } & & $\mathbf{F}$ & $\mathbf{\%}$ & $\mathbf{F}$ & $\mathbf{\%}$ \\
\hline Pendidikan & Rendah & 11 & 29,7 & 4 & 10,8 \\
& Tinggi & 18 & 48,6 & 4 & 10,8 \\
Total & & 29 & 78,4 & 8 & 21,6 \\
\hline
\end{tabular}

\subsubsection{Kepuasan Pasien Menurut Jenis Kelamin}

Berikut distribusi motivasi kepuasan pasien menurut jenis kelamin responden di DAQU Sehat Malang terlihat pada tabel di bawah ini. Dari tabel di bawah ini ditunjukkan bahwa sebagian besar pasien menyatakan bahwa kepuasan pasien berdasarkan jenis kelamin laki-laki dengan kategori puas yaitu $13(35,1 \%)$ responden, sedangkanjenis kelamin perempuan yaitu $16(43,2 \%)$ responden. 
Tabel 7. Distribusi Frekuensi Kepuasan Pasien Menurut Jenis Kelamin di DAQU Sehat Malang

\begin{tabular}{|c|c|c|c|c|c|}
\hline & & \multicolumn{4}{|c|}{ Kepuasan } \\
\hline & & \multicolumn{2}{|c|}{ Puas } & \multicolumn{2}{|c|}{ Kurang Puas } \\
\hline & & $\mathbf{F}$ & $\%$ & $\mathbf{F}$ & $\%$ \\
\hline Jenis & Laki-laki & 13 & 35,1 & 0 & 0,0 \\
\hline Kelamin & Perempuan & 16 & 43,2 & 8 & 21,6 \\
\hline Total & & 29 & 78,4 & 8 & 21,6 \\
\hline
\end{tabular}

\subsection{Analisis Bivariat}

Dari penelitian yang dilaksanakan di DAQU Sehat Malang, Peneliti melakukan uji korelatif Spearman untuk melihat hipotesis korelatif antara waktu tunggu (waiting times) dengan kepuasan pasien. Hasil penelitian yang didapatkan bahwa korelasi antara variabel Waiting Times/waktu tunggu dengan kepuasan pasien adalah bermakna karena nilai signifikan yang diperoleh $(0,005)$ lebih kecil dari nilai signifikan yang digunakan $(p<0,01)$. Nilai korelasi dari hasil uji spearman (r) sebesar $(0,455)$ menunjukkan bahwa arah korelasi positif. Artinya waktu tunggu yang sesuai standar akan membuat responden semakin puas.

Tabel 8. Analisis Hubungan Waktu Tunggu dengan Kepuasan Pasien di DAQU Sehat Malang

\begin{tabular}{lll}
\hline & & Kepuasan Pasien \\
\hline Waiting Times (Waktu Tunggu) & $r$ & 0,455 \\
& $p$ & $0,005(p<0,01)$ \\
& $n$ & 37 \\
\hline
\end{tabular}

\subsection{Pembahasan}

Data karakteristik responden dari hasil penelitian ini menunjukkan bahwa, karakteristik usia dewasa muda (41-60) 26 orang (70,3\%) terbanyak dari 37 responden, karakteristik pendidikan tinggi 22 orang $(64,9 \%)$ terbanyak dari 37 responden, karakteristik jenis kelamin perempuan 24 orang $(64,9 \%)$ terbanyak dari 37 responden.

Hasil penelitian yang didapatkan mengenai hubungan waktu tunggu dengan kepuasan pasien pada variabel Waiting Times/waktu tunggu dengan kepuasan pasien menunjukkan bahwa korelasi antara kedua variabel tersebut adalah signifikan karena nilai signifikansi yang diperoleh $(0,005)$ lebih kecil dari nilai signifikansi yang digunakan $(p<0,01)$. Nilai korelasi dari hasil uji spearman sebesar $(0,455)$ menunjukkan bahwa arah korelasi positif. Artinya waktu tunggu yang sesuai standar akan membuat responden semakin puas.

Hasil penelitian yang didapatkan pada variabel Waiting Times/waktu tunggu dengan kepuasan pasien menunjukkan bahwa korelasi (hubungan) antara kedua variabel tersebut adalah bermakna. Dari hasil penelitian ini terdapat 35 responden $(94,6 \%)$ dengan Waiting times/ waktu tunggu yang kurang dari 45 menit, hal tersebut memperlihatkan bahwa kebanyakan responden sudah merasa puas dengan pelayanan yang diberikan dalam waktu kurang dari 45 menit. 
Dari hasil penelitian yang diperoleh, Waktu tunggu yang paling lama adalah 72 menit, dapat dikatakan bahwa waktu tersebut belum terlalu lama sebab standar waktu tunggu yang ditetapkan oleh PERMENKES 2008 sendiri adalah 60 menit. Selain itu ada beberapa faktor Iain yang diduga berpengaruh terhadap rasa puas pada setiap pasien yang datang berobat ke DAQU Sehat Malang termasuk salah satu diantaranya adalah fasilitas (sarana dan prasarana) seperti media elektronik (televisi), ruang tunggu yang nyaman dan bersih, tempat duduk pengunjung yang cukup memadai, media massa (majalah ataupun koran) yang disediakan oleh pihak RS di ruang tunggu di bagian pelayanan klinik DAQU dapat digunakan dengan mudah dan fleksibel oleh setiap pasien maupun keluarga yang berkunjung di poliklinik. Sehingga dapat dikatakan lama menunggu (waktu tunggu) kurang berpengaruh terhadap rasa kepuasan pada pasien yang datang berobat ke DAQU Sehat Malang.

Hal ini berarti hasil penelitian yang telah dilakukan telah mendekati standar waiting times/waktu tunggu yang baik/ideal yang telah ditetapkan dan pasien yang berkunjung diharapkan akan merasa puas dengan waiting times/waktu tunggu yang sebentar atau tidak memakan waktu yang lama, karena pelayanan yang lambat, maka pasien akan cenderung merasa jenuh menunggu dan tidak puas terhadap pelayanan yang diberikan.

\section{Simpulan}

Kebanyakan responden merasa waiting times dengan kategori baik/sesuai standar yaitu $35(94,6 \%)$ responden, dan sebagian merasa bahwa waiting times dengan kategori kurang baik/tidak sesuai standar yaitu $2(5,4 \%)$ responden. Kepuasan pasien menurut responden di DAQU Sehat Malang menunjukkan bahwa kebanyakan responden merasa puas yaitu 29 $(78,4 \%)$ responden, sedangkan yang kurang puas sebanyak $8(21,6 \%)$ responden. Korelasi antara Waiting Times/waktu tunggu dengan kepuasan pasien adalah bermakna karena nilai signifikan yang diperoleh $(0,005)$ lebih kecil dari nilai signifikan yang digunakan $(p<0,01)$. Nilai korelasi dari hasil uji spearman (r) sebesar $(0,455)$ menunjukkan bahwa arah korelasi positif. Artinya waktu tunggu yang sesuai standar akan membuat responden semakin puas. Dari hasil penelitian yang diperoleh, Waktu tunggu yang paling lama adalah 72 menit, dapat dikatakan bahwa waktu tersebut belum terlalu lama sebab standar waktu tunggu yang ditetapkan oleh PERMENKES 2008 sendiri adalah 60 menit. Sehingga hal ini perlu mendapat perhatian dari pihak DAQU Malang. Pihak pengelola hendaknya meningkatkan kepuasan pasien khusus bagi pasien yang kurang puas dengan cara menambah jumlah tempat duduk di ruang tunggu, karena pertanyaan ini memiliki skor yang paling rendah, sehingga perlu ditingkatkan.

\section{Daftar Rujukan}

Acuin, C. S., Khor, G. L., Liabsuetrakul, T., Achadi, E. L., Htay, T. T., Firestone, R., \& Bhutta, Z. A. (2011). Maternal, neonatal, and child health in southeast Asia: towards greater regional collaboration. The Lancet, 377(9764), 516-525.

Solikhah, S., Amani, M. N., \& Kadar, A. (2009). Skrining Malaria di Wilayah Kerja Puskesmas Banyuasin Kecamatan Loano Kabupaten Purworejo Propinsi Jawa Tengah. Kes Mas: Jurnal Fakultas Kesehatan Masyarakat Universitas Ahmad Daulan, 3(3), 24864.

BPS Jatim. (2017). Laporan Eksekutif Kesehatan Provinsi Jawa Timur Tahun 2016. Surabaya: Badan Pusat Statistik Provinsi Jawa Timur.

Burke, B. T., Miller, B. F., Proser, M., Petterson, S. M., Bazemore, A. W., Goplerud, E., \& Phillips, R. L. (2013). A needs-based method for estimating the behavioral health staff needs of community health centers. $B M C$ Health Services Research, 13(1), 1-12.

Dinkes Jatim. (2016). Profil Kesehatan Provinsi Jawa Timur Tahun 2015. Dinas Kesehatan Provinsi Jawa Timur. 
Sport Science and Health, 3(10), 2021, 800-807

Djannah, S. N., Suryani, D., \& Purwati, D. A. (2009). Hubungan tingkat pengetahuan dan sikap dengan perilaku pencegahan penularan TBC pada mahasiswa di asrama manokwari Sleman Yogyakarta. Universitas Ahmad Dahlan. 